\title{
Heterotrophic nitrogen removal bacteria in sedimentary and water of striped catfish ponds in the Mekong Delta, Vietnam
}

\author{
Cao Ngoc Diep ${ }^{1,2, *}$, Nguyen Thi Kim Cuc ${ }^{1,2}$ \\ ${ }^{1}$ Dept. Microbiology Biotechnology, Can Tho City, Vietnam; Institute of Marine Biochemistry, Ha Noi city, Vietnam \\ ${ }^{2}$ Biotechnology R\&D Institute, Can Tho University, Can Tho City, Vietnam; Vietnam Academy Institute of Science and Technology, Ha \\ Noi City, Vietnam
}

\section{Email address:}

cndiep@ctu.edu.vn (C. Ngoc Diep), kcnguyenthi@gmail.com (N. Thi Kim Cuc)

To cite this article:

Cao Ngoc Diep, Nguyen Thi Kim Cuc. Heterotrophic Nitrogen Removal Bacteria in Sedimentary and Water of Striped Catfish Ponds In The Mekong Delta, Vietnam. American Journal of Life Sciences. Vol. 1, No. 1, 2013, pp. 6-13. doi: 10.11648/j.ajls.20130101.12

\begin{abstract}
A total of 1682 heterotrophic nitrogen removal (HNR) bacteria isolated from sedimentary and water of striped catfish ponds were classified in four kinds of heterotrophic ammonia-oxidizing bacteria (402 isolates), nitrite-oxidizing bacteria (438 isolates), nitrate-oxidizing bacteria (444 isolates) and heterotrophic nitrifying and denitrifying bacteria (398 isolates). The virtually complete $16 \mathrm{~S}$ rRNA gene was PCR amplified and sequenced. The sequences from the selected HNR bacteria showed high degrees of similarity to those of the GenBank references strains (between 97\% and 99.8\%). Phylogenetic trees based on the 16S rDNA sequences displayed high consistency, with nodes supported by high bootstrap (500) values. These presumptive HNR isolates were divided four groups that included members of genera Arthrobacter, Corynebacterium, Rhodococcus (high $\mathrm{G}+\mathrm{C}$ content gram-positive bacteria), Bacillus (low $\mathrm{G}+\mathrm{C}$ content gram-positive bacteria) and Pseudomonas (gram-negative bacteria). Based on Pi value (nucleotide diversity), heterotrophic ammonium-oxidizing bacteria group had highest values and heterotrophic nitrifying-denitrifying bacteria group had the lowest values and Theta values (per sequence) from S of SNP for DNA polymorphism showed that heterotrophic nitrate-oxidizing bacteria group had the highest theta values in comparison of three groups. The present study, the HNR bacteria from sedimentary and water of striped catfish ponds, showed a very diverse community of HNR bacteria with a relatively high number of species involved in sedimentary and water samples and many isolates have nitrogen utilization ability at high concentration (800 $1200 \mathrm{mM}$ ) and high $\mathrm{G}+\mathrm{C}$ gram-positive bacteria strain occupied higher than low $\mathrm{G}+\mathrm{C}$ gram-positive bacteria strain.
\end{abstract}

Keywords: Heterotrophic Nitrogen Removal, 16S Rrna Gene Sequence, Biologic Nitrogen Removal, Sedimentary And Water Of Striped Catfish Ponds, Gram-Positive Bacteria

\section{Introduction}

The Mekong delta has a total freshwater area of 641,350 ha or $67.2 \%$ total water surface [1]; This delta has the most diversified farming activities and great potentail for increased aquaculture production and Catfish farming started at the beginning of the 1960s that included catfish (Pangasius bacourti)(Vietnamese name: basa) cultured in small cages and striped catfish (Pangasianodon hypophthalmus)(Vietnamese name: tra) cultured mostly in latrine ponds [1]. Striped catfish culture in the Mekong delta is considered a success story of aquaculture in Vietnam with the production and export turnover reached 1,200,000 t worth UD\$ 1 billion in 2007; this result in new chalenges for strped catfish production to change towards more sustainable production with respect to its environmental impact [2].

Water quality in catfish production systems in the Mekong Delta was investigated to assess the potential impacts of this activity on the environment. The feed has been used to catfish with low quality as low protein, high carbohydrate content extensively and the residue of feed and catfish fall down in the bottom of ponds and they have used the anaerobic bacteria and the toxicities have released in the water as ammonia, hydrogen sulfur.....[3]. High N (especially ammonia) in fish-pond water may be toxic to fish and it may be cause eutrophication in canals, streams, small rivers, it threatens the quality of water used for household purposes by many farm-families. Nitrification is the process of converting ammonia to nitrate via nitrite and is mediated by two 
groups of chemolithoautotrophic bacteria, ammonia-oxidizing bacteria $(\mathrm{AOB})$ and nitrite-oxidizing bacteria [4]. Denitrification is part of the bioenergetic apparatus of the bacteria cell, where the $\mathrm{N}$ oxidations nitrate and nitrite and the gasous $\mathrm{N}$ oxides $\mathrm{NO}$ and $\mathrm{N}_{2} \mathrm{O}$ serve in lieu of $\mathrm{O}_{2}$ as terminal acceptors for electron transport phosphorylation. Nitrogen removal (i.e., the conversion of ammonium and organic nitrogen to nitrogen gas forms) by heterotrophic microorganisms has attached increasing interest recently in wastewater treatment [5][6] and they has usually been reported as the result of simultaneous heterotrophic nitrification and aerobic denitrification [7]. Specifically, the pathway has been widely accepted as the removal of $\mathrm{NH}_{4}{ }^{+}$to $\mathrm{NO}_{2}{ }^{-}$or $\mathrm{NO}_{3}{ }^{-}$(heterotrophic nitrification) and simultaneously aerobic conversion of the $\mathrm{NO}_{3}{ }^{-}$or $\mathrm{NO}_{2}{ }^{-}$to $\mathrm{N}_{2} \mathrm{O}$ and/or $\mathrm{N}_{2}$ (aerobic denitrification) as Alcaligenes faecalis [8], Bacillus sp. [9], Acinetobacter calcoaceticus [10] and they were isolated from other different sludges.

At present, molecular methods based on 16S rRNA has been used widely to study the population structure of bacteria domain. In this study, molecular methods based on $16 \mathrm{~S}$ rRNA was used to identify the population composition of heterotrophic nitrogen removal (HNR) bacteria and drop plate count method [11](Hoben and Somasegaran, 1982) to enumerate HNR bacteria in sedimentary and water of striped catfish ponds in the Mekong Delta, Vietnam. The aims of this study were to quantify HNR bacteria populations and identify their diversity in sedimentary and water of striped catfish ponds and isolates were identified gram staining, population and selected representative strains were identified at the molecular level using 16S rRNA sequence analysis.

\section{Method}

\subsection{Isolation of Heterotrophic Nitrogen Removal Bacteria (HNRB)}

The sources for isolating micro-organisms were solid waste (sedimentation) and wastewater of catfish-ponds (10 provinces/city) in the Mekong Delta (Figure 1), samples were stored at $15-20^{\circ} \mathrm{C}$ in plastic containers and they were moved to laboratory to stored in the refregirator.

\subsection{Media}

Media were used in this study [10] with a standard medium was prepared for enrichment and isolation of bacteria by dissolving $10 \mathrm{~g}$ of peptone, $10 \mathrm{~g}$ of beef extract, and $5 \mathrm{~g}$ of $\mathrm{NaCl}$ in distilled water (per liter). This standard medium was autoclaved for $30 \mathrm{~min}$ at $121^{\circ} \mathrm{C}$.

The ingredients of a basal medium in $100 \mathrm{ml}$ distilled water ( $\mathrm{pH} 8$ ) were as follows: $0.4 \mathrm{~g}$ of $\mathrm{NaCl}, 2.15 \mathrm{~g}$ of $\mathrm{Na}_{2} \mathrm{HPO}_{4}, 0.09 \mathrm{~g}$ of $\mathrm{KH}_{2} \mathrm{PO}_{4}$ and $3 \mathrm{ml}$ of trace elements solution. The trace elements solution contained $0.3 \mathrm{~g}$ of $\mathrm{MgSO}_{4} \cdot 7 \mathrm{H}_{2} \mathrm{O}, 0.1 \mathrm{~g}$ of $\mathrm{MnSO}_{4}, 0.112 \mathrm{~g}$ of $\mathrm{H}_{3} \mathrm{BO}_{3}, 0.03 \mathrm{~g}$ of $\mathrm{FeSO}_{4} .7 \mathrm{H}_{2} \mathrm{O}$ and $0.06 \mathrm{~g}$ of $\mathrm{CaCl}_{2}$ (per liter). Different amounts of nitrogen and organic carbon sources were added to basal medium for groups of nitrifiers or denitrifiers (Table 1). Each basal medium was autoclaved for $15 \mathrm{~min}$ at $110^{\circ} \mathrm{C}$. The chemicals were purchased from Merck.

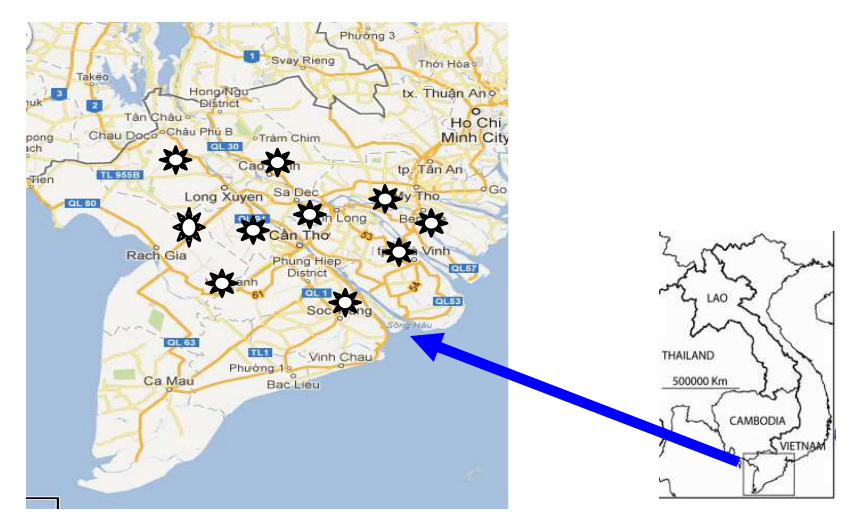

Figure 1. Samples were collected at sedimentary and water of striped catfish ponds of ten city/provinces (*) in the Mekong Delta, Vietnam (from Google map).

Table 1. List of nitrogen and carbon amount added in the basal medium (per $100 \mathrm{ml}$ ).

\begin{tabular}{|c|c|c|c|c|}
\hline \multirow[t]{2}{*}{ Component } & \multicolumn{4}{|c|}{$\underline{\text { Nitrogen and carbon amount }}$} \\
\hline & $\mathbf{A}$ & B & C & D \\
\hline${ }^{\mathrm{a}} \mathrm{NH}_{4} \mathrm{Cl}$ solution $(\mathrm{ml})$ & 12 & & & 4 \\
\hline${ }^{\mathrm{b}} \mathrm{NaNO}_{2}$ solution $(\mathrm{ml})$ & & 4 & & 4 \\
\hline${ }^{\mathrm{c}} \mathrm{NaNO}_{3}$ solution $(\mathrm{ml})$ & & & 4 & 4 \\
\hline Glucose (g) & 0.3 & 0.1 & 0.1 & 0.3 \\
\hline \multicolumn{5}{|c|}{${ }^{a}$ contained $1 \mathrm{mg} / \mathrm{ml}$ of $\mathrm{NH}_{4}^{+}-\mathrm{N}$} \\
\hline \multicolumn{5}{|c|}{${ }^{b}$ contained $1 \mathrm{mg} / \mathrm{ml}$ of $\mathrm{NO}_{2}^{-}-\mathrm{N}$} \\
\hline
\end{tabular}

\subsection{Count and isolation of Bacteria in the Material}

The samples were agitated to obtain homogeneous suspensions between water and sedimentary in sterile distilled water. Suspended liquid $(100 \mu \mathrm{l})$ was piped into a tube $(10$ $\mathrm{ml})$ that contained the standard medium. After $48 \mathrm{~h}$ of aerobic incubation at $30^{\circ} \mathrm{C}$ and $120 \mathrm{rpm}, 1 \mathrm{ml}$ suspended liquid were suspended in $90 \mathrm{ml}$ of sterile distilled water in flask-250 $\mathrm{mL}$ for $10 \mathrm{~min}$ a shaker [New Brunicks, USA]. The supernatant was appropriately diluted using sterile distilled water with $10^{-2}, 10^{-3} \ldots$ dilution. Five drops put on the media A (for ammonium), the media B (for nitrite), the media $\mathrm{C}$ (for nitrate) and the media D (combination of ammonium, nitrite, nitrate) with each dilution and they were incubated in $30^{\circ} \mathrm{C}$. After 24 or $48 \mathrm{~h}$, generated colonies were counted for calculating colony-forming units per $1 \mathrm{ml}$ or $1 \mathrm{~g}$ of dry matter (CFU g $\left.{ }^{-1} \mathrm{DM}\right)$. Simulteneously, each isolate was cultivated in each medium to detect the ability of ammonium, nitrite, nitrate or combination of three kinds of above nitrogen. Purified isolates were obtained by repeated streaking on fresh agar plates. A bacterium with high nitrogen removal efficiency was obtained and named and they were suspended in $20 \%$ glycerol solution at $-80^{\circ} \mathrm{C}$ for 
long-term storage.

\subsection{DNA Extraction, PCR Amplification and 16S rRNA Gene Sequence Analysis}

DNA was extracted from a bacterial suspension $(1 \mathrm{ml}$ from a TSB medium at $30^{\circ} \mathrm{C}$ and $120 \mathrm{rpm}$ for $24 \mathrm{~h}$ ) to DNA protocol of Neumann et al. [12]. Primers 8F (5'AGAGTTTGATCCTGGCTCAG-3') and 1492R (5'-TACGGTTACCTTGTTACGACTT-3')[13] were used to amplify $16 \mathrm{~S}$ rRNA gene by a PCR protocol. Amplification was performed in a total volume of $50 \mu \mathrm{l}$ in $0.2 \mathrm{ml}$ Eppendorf tubes using a DNA thermocycle (BioRAD). The reaction mix was prepared using the following: $1 \mathrm{x}$ PCR buffer (20 mM Tris-HCl-NH $\left.\mathrm{NO}_{4}\right)$ with $5 \mu \mathrm{l}, 4 \mu \mathrm{dNTP}(20$ nmol of each deoxynucleoside triphosphate), $2 \mu$ primer $8 \mathrm{~F}$; $2 \mu \mathrm{l}$ primer $1492 \mathrm{R}$ (30 pmol of each primer), $0.5 \mu \mathrm{l} \mathrm{BSA}$ (100 $\mu \mathrm{g}$ of bovine albumin per $\mathrm{ml}), 2 \mu \mathrm{l}$ of template DNA and 2.5 U of Taq DNA polymerase (Fermentas, Singapore)

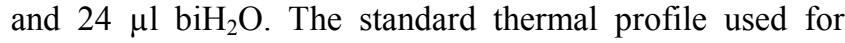
amplification of the $16 \mathrm{~S}$ rRNA sequence was as follows: 5 min at $95^{\circ} \mathrm{C}$; then 30 cycles consisting of $30 \mathrm{~s}$ at $94^{\circ} \mathrm{C}(\mathrm{de}-$ naturation), $30 \mathrm{~s}$ at $53^{\circ} \mathrm{C}$ (annealing), and $90 \mathrm{~s}$ at $72^{\circ} \mathrm{C}$ (elongation) and a final cycle of consisting of $10 \mathrm{~min}$ at $72^{\circ} \mathrm{C}$. Aliquots $(10 \mu \mathrm{l})$ of PCR products were electrophoresed and visualized in $1 \%$ agarose gels using standard electrophoresis procedures. Partial 16S rRNA gene of selectived isolates in each nitrogen group was sequenced by MACROGEN, Republic of Korea (dna.macrogen.com). Finally, 16S rRNA sequence of the isolate was compared with that of other microorganisms by way BLAST (http://www.ncbi.nlm.nih.gov/BLAST/Blast.cgi); In each site (city or province) and the best isolate(s) (bacterial isolate can utilize the highest nitrogen concentration) in every group (bacteria utilize ammonia, nitrite, nitrate or combination of three nitrogen kinds) and 10 isolates of 10 sites were chosen to sequence and the results were compared to sequences of GenBank based on partial 16S rRNA sequences to show relationships between heterotrophic nitrogen strains [14] and phylogenetic tree were constructed by the neighbor-joining method based on 500 bootstraps.

\subsection{SNPs Discovery}

The sequence data from 64 nitrogen removal bacterial isolates were analysed with SeqScape@ Software (Applied Biosystem, Foster City, CA, USA). SeqScape is a sequence comparison tool for variant identification, SNP discovery and validation. It considers alignment depth, the base calls in each of the sequences and the associated base quality values. Putative SNPs were accepted as true sequence variants if the quality value exceeded 20 . It means a $1 \%$ chance basecall is incorrect.

\subsection{Nucleotide Diversity ( $\theta)$}

Nucleotide diversity $(\Theta)$ was calculated by the method described by Halushka et al. [15]. $n$

$$
\Theta=\mathrm{K} / \mathrm{aL} \underset{i=2}{\mathrm{a}} \quad \mathrm{a}=\sum \mathrm{l} /(i-1)
$$

where $\mathrm{K}$ is the number of SNPs identified in an alignment length, $\mathrm{n}$ is alleles and $\mathrm{L}$ is the total length of sequence (bp).

\section{Results and Discussion}

The suspended solid wastewaters have high concentration of ammonia and pH varied from 4.12 to 7.47 (Table 2) especially $\mathrm{pH}$ of sedimentary and water from striped catfish ponds related with nitrogen removal bacterial population closely (Figure 2).

Table 2. $p H$ and nitrogen concentrations in piggery sewage of 13

\begin{tabular}{|c|c|c|c|}
\hline \multirow[t]{2}{*}{ Location } & \multirow[t]{2}{*}{ pH } & \multicolumn{2}{|c|}{$\begin{array}{c}\mathrm{NH}_{4}{ }^{+} \text {concentration } \\
\text { in sewage } \\
(\mathrm{mg} / \text { wet litre })\end{array}$} \\
\hline & & Dry season & Wet season \\
\hline AN GIANG & $3.53-7.52$ & $105-557$ & $2110-2430$ \\
\hline BẠC LIÊU & $4.86-7.10$ & $1226-1710$ & $132-1596$ \\
\hline BẾN TRE & $4.63-7.08$ & $1036-2018$ & $122-458$ \\
\hline CÀ MAU & $3.73-7.33$ & $521-584$ & $127-386$ \\
\hline CẦN THƠ & $4.32-7.11$ & $68-113$ & $59-68$ \\
\hline ĐỒNG THÁP & $5.55-7.05$ & $3000-3331$ & $30-53$ \\
\hline HẬU GIANG & $4.03-7.58$ & $185-4270$ & $42-4056$ \\
\hline LONG AN & $4.95-7.49$ & $1313-1877$ & $963-1071$ \\
\hline KIÊN GIANG & $4.01-7.33$ & $448-755$ & $125-154$ \\
\hline SÓC TRĂNG & $6.51-8.02$ & $18-23$ & $370-401$ \\
\hline TIÊN GIANG & $5.71-7.41$ & $616-837$ & $854-903$ \\
\hline TRÀ VINH & $5.61-7.93$ & $657-679$ & $92-152$ \\
\hline VĨNH LONG & $5.56-7.44$ & $1313-1877$ & $42-4056$ \\
\hline
\end{tabular}
city/provinces in the Mekong Delta, Vietnam.

From 159 sedimentary+water samples of striped catfish pond, 1682 heterotrophic nitrogen removal bacterial isolates were isolated with 402 heterotrophic ammonia-oxidizing bacteria (HAOB) isolates, 438 heterotrophic nitrite-oxidizing bacteria $(\mathrm{HNiOB})$ isolates, 444 heterotrophic nitrate-oxidizing bacteria $(\mathrm{HNaOB})$ isolates and 398 heterotrophic nitrifying and denitrifying bacteria (HNDB) isolates (Table 3) especially many isolates can utilize at high concentration $(800-1200 \mathrm{mM})($ ammonium, nitrite or nitrate) in each group however the bacterial isolates having three kinds of nitrogen ability only grew on $300 \mathrm{mM}$ (ammonium+nitrite+nitrate) media. 


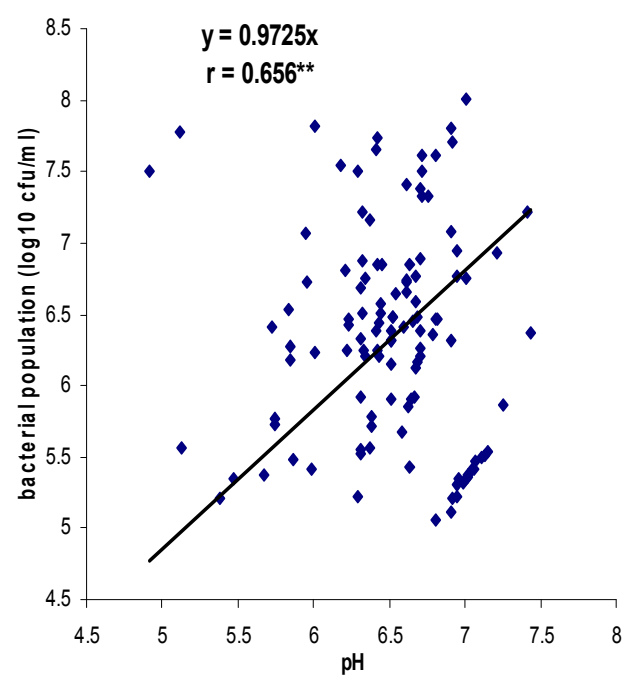

Figure 2. Correlation between $\mathrm{pH}$ and nitrogen removal bacterial population in sedimentary and water of striped catfish pond samples in 10 city/provinces on the Mekong Delta, Vietnam.

Table 3. Nitrogen removal bacterial isolates isolated from 159 sedimentary and water samples from striped catfish ponds in 10 city/provinces of the Mekong Delta, Vietnam.

\begin{tabular}{lllllll}
\hline No & $\begin{array}{l}\text { City/ } \\
\text { province }\end{array}$ & $\begin{array}{l}\text { HA } \\
\text { OB }\end{array}$ & $\begin{array}{l}\text { HNi } \\
\text { OB }\end{array}$ & $\begin{array}{l}\text { HNa } \\
\text { OB }\end{array}$ & Combination* \\
\hline 01 & An Giang & 55 & 65 & 52 & 75 & 247 \\
02 & Ben Tre & 29 & 45 & 51 & 37 & 162 \\
03 & Can Tho & 49 & 61 & 51 & 5 & 166 \\
04 & Dong Thap & 58 & 55 & 55 & 51 & 219 \\
05 & Hau Giang & 66 & 67 & 65 & 77 & 275 \\
06 & Kien Giang & 22 & 29 & 31 & 32 & 114 \\
07 & Soc Trang & 42 & 33 & 47 & 44 & 166 \\
08 & Tien Giang & 13 & 30 & 32 & 10 & 85 \\
09 & Tra Vinh & 40 & 27 & 18 & 27 & 112 \\
10 & Vinh Long & 28 & 26 & 42 & 40 & 136 \\
\hline & & & 438 & 444 & 398 & \\
\hline
\end{tabular}

HAOB: Heterotrophic Ammonium Oxidation Bacteria

HNiOB: Heterotrophic Nitrite Oxidation Bacteria

HNaOB: Heterotrophic Nitrate Oxidation Bacteria

* bacterial isolates utilize three kinds of nitrogen (ammonium, nitrite, nitrate)

** total of four groups

Their colonies have round-shaped or not identified; milky; light brown, pink yellow; entire or lobate margin (Fig. 3) and all of them are Gram-positive by Gram stain. The cells were observed by SEM and appeared as short rods and most of them have motility (Figure 4).

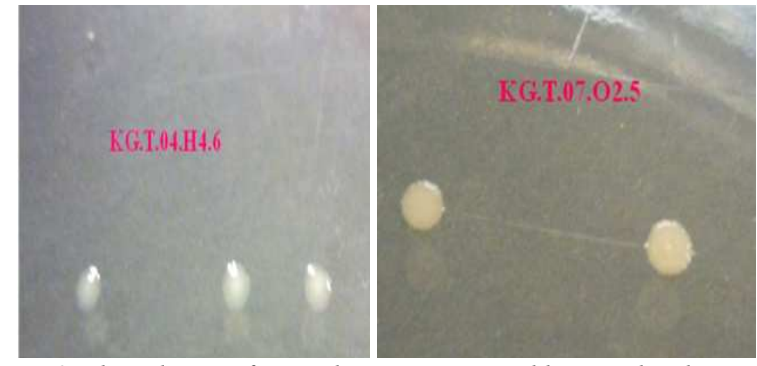

Figure 3. The colonies of several nitrogen removal bacterial isolates.
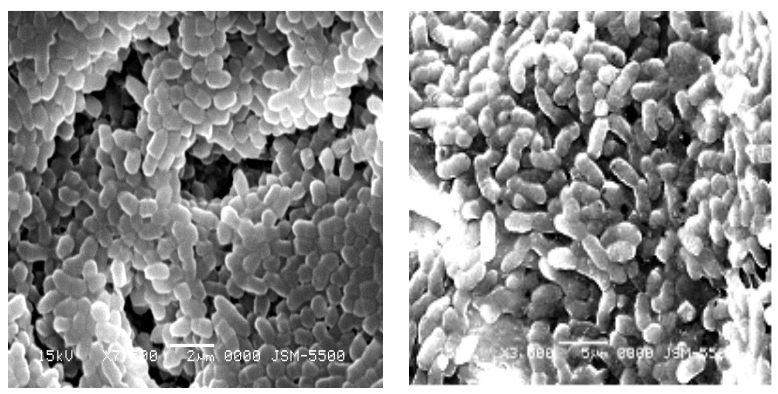

Figure 4. Scanning electron micrograph of two nitrogen removal bacterial isolates.

The fragments of $1485 \mathrm{bp} 16 \mathrm{~S}$ rRNA were obtained from PCR and sequencing. Homology searches of the 16S rRNA gene sequence of selected strain in GenBank by BLAST revealved that they had high similarity to sequences of Firmicutes phylum. A neighbor-joining phylogenetic tree in HAOB group showing the two clusters: big cluster with two clusters as cluster A1 Bacillus with VINHLONG, BENTRE, SOCTRANG, TRA VINH, KIEN GIANG isolates and cluster A2 with DONGTHAP, ANGIANG, CANTHO, HAU GIANG were classified as Arthrobacter. Cluster B with TIENGIANG was identified as Pseudomonas (Gram-negative bacteria)(Figure 5). The results showed that HAOB group had relationship closely even through they were isolated from various sites in the Mekong Delta.

In HNiOB group, phylogenetic tree showed that two clusters with genus Arthrobacter and Rhodococcus (high $\mathrm{G}+\mathrm{C}$ gram-positive bacteria) in cluster A with HAUGIANG, VINHLONG, BENTRE, DONGTHAP, CANTHO, SOCTRANG and Bacillus and Pseudomonas (gram-negative bacteria) in cluster B with ANGIANG, TIENGIANG, KIENGIANG, TRAVINH (Figure 6).

In Figure 7 presented two clusters in $\mathrm{HNaOB}$ group with SOCTRANG, CANTHO, VINHLONG, KIENGIANG, HAUGIANG, TRAVINH, ANGIANG, BENTRE isolates were determined as genus Bacillus in cluster A while cluster B composed of TIENGIANG and DONGTHAP isolates were genus Corynebacterium and Arthrobacter. With HNDB group, phylogenetic tree showed that two clusters: cluster A composed of cluster A with ANGIANG, SOCTRANG, KIENGIANG, TRAVINH isolates in genera $\mathrm{Ba}$ cillus and cluster B1 with HAUGIANG and TIENGIANG isolates were genus Rhodococcus and cluster B2 with BENTRE, CANTHO, DONGTHAP isolates were classified in genus Arthrobacter (Figure 8). 


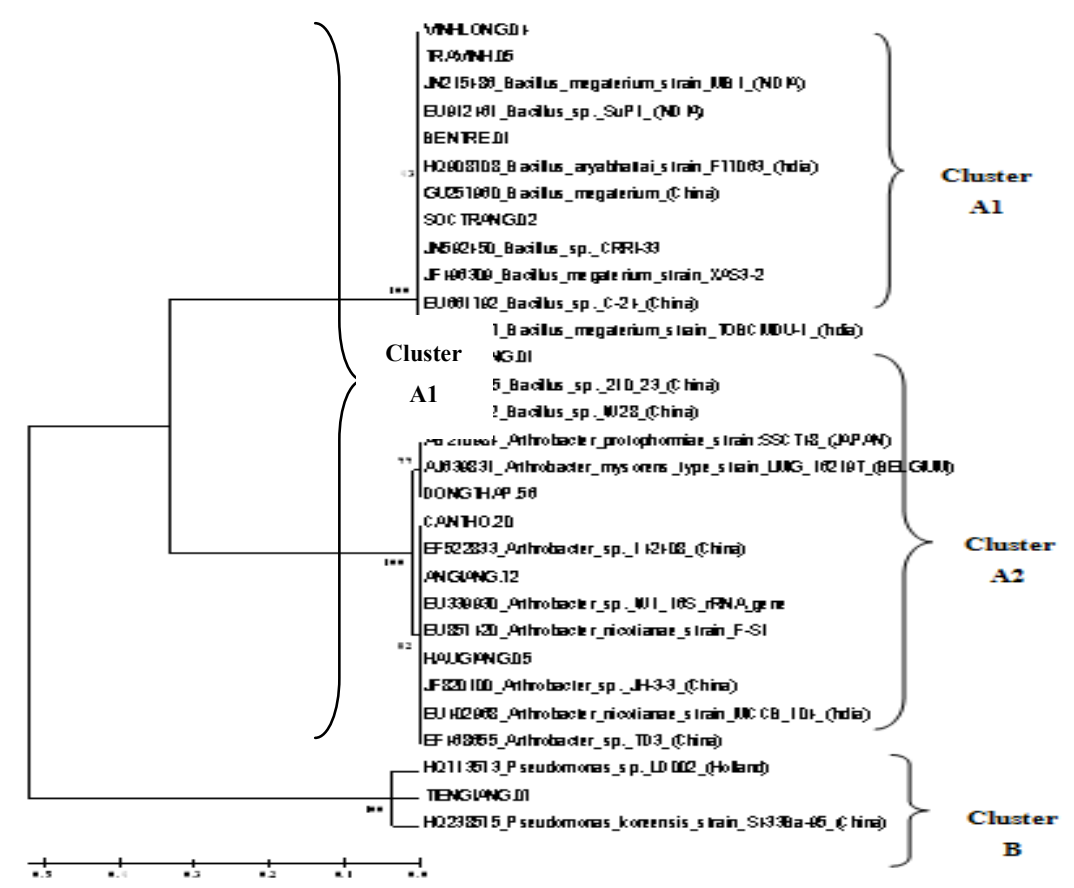

Figure 5. Phylogenetic tree showing the relative position of $H A O B$ (ammonia utilization) by the neighbor-joining method of complete 16S rRNA sequences. Bootstrap values of 500 replicates are shown at the nodes of the trees.

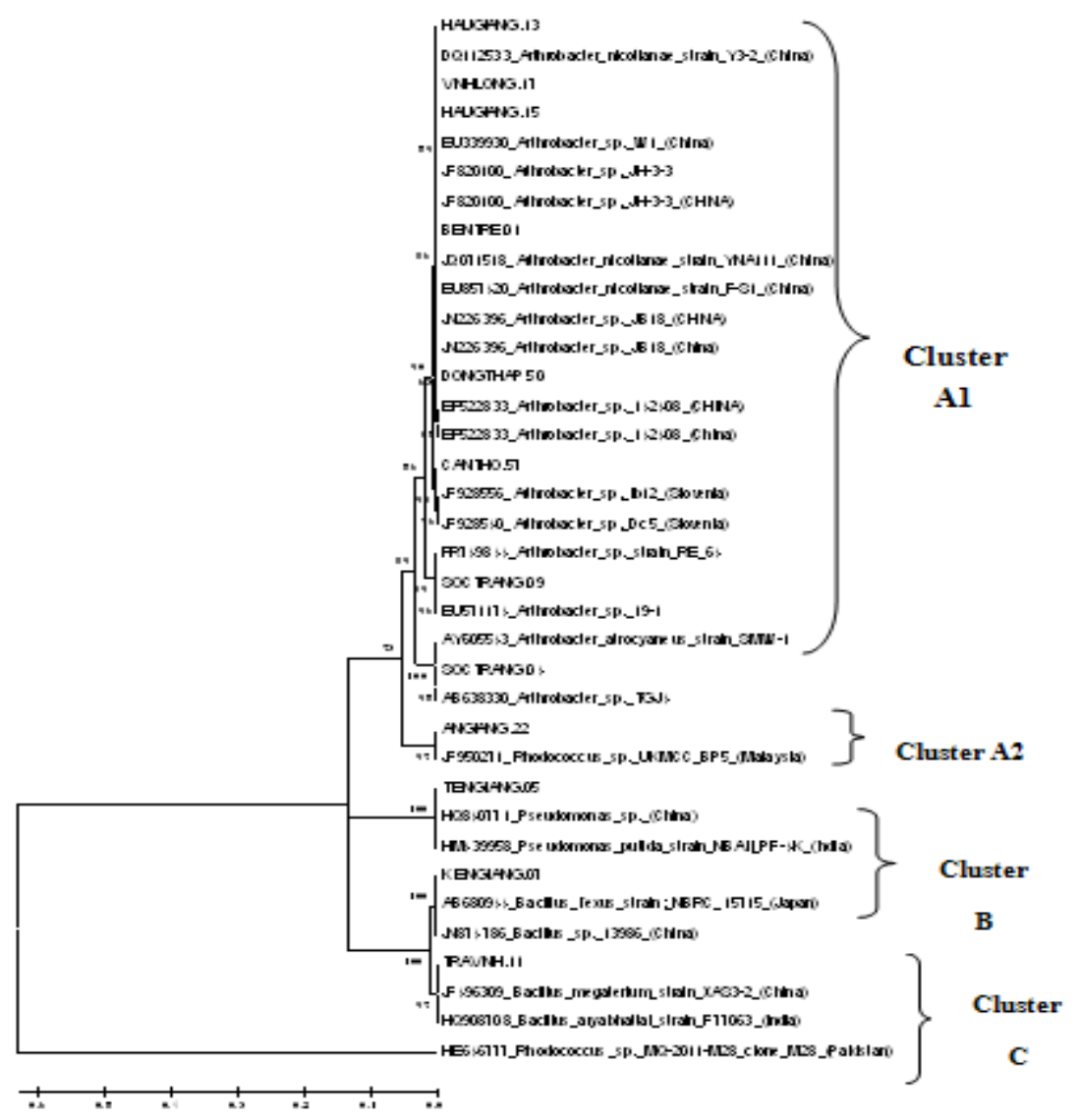

Figure 6. Phylogenetic tree showing the relative position of HNiB (nitrite utilization) by the neighbor-joining method of complete $16 \mathrm{~S}$ rRNA sequences. Bootstrap values of 500 replicates are shown at the nodes of the trees. 


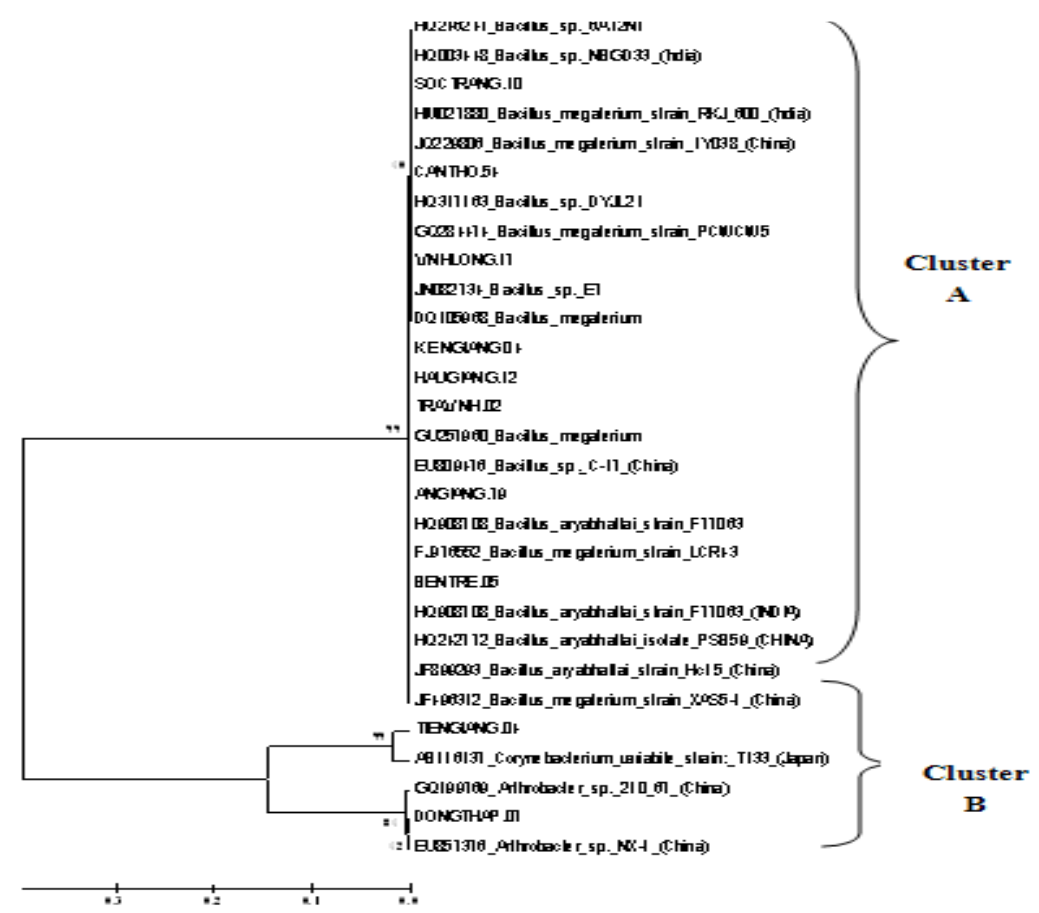

Figure 7. Phylogenetic tree showing the relative position of HNaB (nitrate utilization) by the neighbor-joining method of complete 16S rRNA sequences. Bootstrap values of 500 replicates are shown at the nodes of the trees.

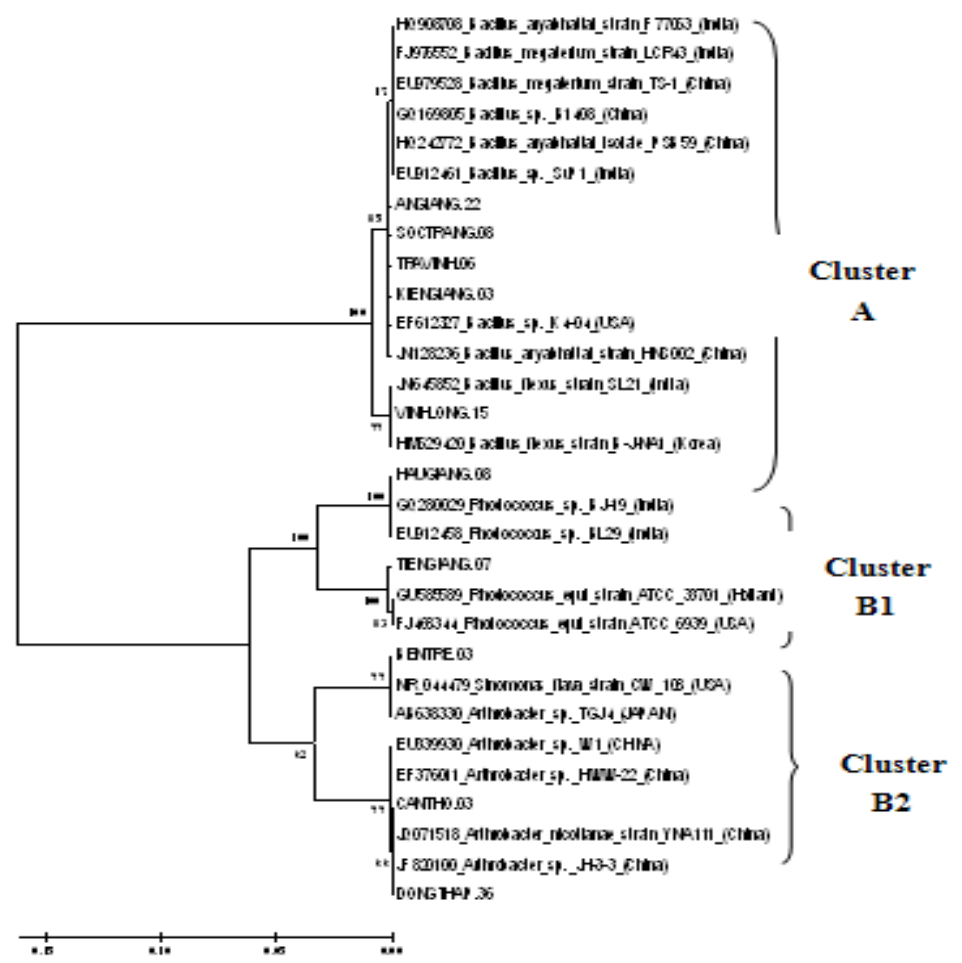

Fig.8. Phylogenetic tree showing the relative position of HNDB (ammonia, nitrite, nitrate utilization) by the neighbor-joining method of complete $16 \mathrm{~S} r R N A$ sequences. Bootstrap values of 500 replicates are shown at the nodes of the trees.

Nucleotide polymorphism can be measured by many methods, for example, haplotype (gene) diversity, nucleotide diversity, $(\mathrm{Pi})$, Theta $(\Theta)$ (per sitr) etc.

In this study, nucleotide diversity was estimated as Theta $(\Theta)$, the number of segregating sites [16], and its standard deviation $(\mathrm{S} \Theta)$. These parameters were estimated by DNA
Sequence Polymorphism software version 4.0 [17].

Pi value explained nucleotide diversity of sequences for each gene. The higher values, the more diversity among HAOB group had highest values and HNDB group had the lowest values. Theta values (per sequence) from S of SNP for DNA polymorphism were calculated for each group. 
$\mathrm{HNaOB}$ group had the highest theta values in comparison of three groups (Table 4).

Table 4. Nucleotide diversity $(\theta)$ values of two ESTs using the programme DNASp 4.0 [17].

Primer $8 F$ 5'- AGAGTTTGATCCTGGCTCAG-3'

Primer 1492R 5'-TACGGTTACCTTGTTACGACTT-3'

\begin{tabular}{llcll}
\hline ESTs & HAOB & HNiOB & HNaOB & HNDB \\
\hline $\begin{array}{l}\text { Nucleotide } \\
\text { diversity }\end{array}$ & 0.72447 & 0.71805 & 0.72206 & 0.70353 \\
$\begin{array}{l}\text { (Pi) } \\
\text { Theta (per }\end{array}$ & 238.91 & \pm 293.57 & 318.70 & \\
$\begin{array}{l}\text { sequence) } \\
\text { from S }\end{array}$ & 81.46 & \pm 110.13 & \pm 119.53 & $238.62 \pm 81.37$ \\
\hline
\end{tabular}

Water pollution is one of the challenges, which threatens the striped catfish culture and environment and TAN concentration in water of catfish ponds varied from 0.033 $4.602 \mathrm{mh} / \mathrm{L}$ and the catfishes died in ponds when TAN concentration was higher $2.0 \mathrm{mg} / \mathrm{L}$ [18] however high TAN concentration in water of catfish-ponds (in dry-season) has been diluted and removed by the rains and the flood from Mekong river in the wet-season therefore TAN concentration in water of catfish-ponds is lower than in wet-season (Table 2). Many strains of Pseudomonas stutzeri were isolated and identified in sedimentary and water of catfish-ponds in the Mekong Delta, Vietnam and many bacteria isolates can oxidize ammonia in the water and a few of isolates has high ammonia oxidation ability and they were applied to remove nitrogen in water of catfish-ponds [19]. Pseudomonas stutzeri strains have strong ability to remove nitrogen in wastewater in piggery wastewater [20] and they reported that $P$. stutzeri NS-2 strain had excellent denitrifying capability under aerobic and anaerobic conditions, as revealed by nitrate disappearance and nitrogen gas production. Nguyen et al. [21] reported that Bacillus is the most common group used for treating water pollution in aquaculture ponds. It comprises three common species including Bacillus subtilis, Bacillus licheniformis and Bacillus megaterium.

\section{Conclusion}

Bacillus is main genus in nitrogen remove bacteria groups which was found in sedimentary and water of striped catfish-ponds in the Mekong Delta, Vietnam and the best heterotrophic nitrogen removal strains will be applied to treat water pollution in catfish ponds.

\section{Acknowledgements}

This work was supported by Ministry of Science and Technology, Vietnam Government. The author thank the helpness of Biotechnology MSc. students and technicians in the Environment Microbiology Laboratory, Biotechnology R\&D Institute, Can Tho University, Vietnam

\section{References}

[1] N.T. Phuong, D.T.H. Oanh, and N.A. Tuan, "Striped catfish (Pangasianodon hypophthalmus) Aquacultre in Viet nam: An Unprecedented development within a Decade," Aquaculture in Vietnam: Present Status and Challenges for Sustainable Development. Handbook and Abstracts from Conference at Can Tho University, Can Tho city, Vietnam, p.25, 2008.

[2] G. Van der Vorst, L.M. Triet, P. Sorgeloos, and J. Dewult, "Using life cycle assessment methods and thermodynamics for the evaluation of susyainable processing of Pangasius waste," Aquaculture in Vietnam: Present Status and Challenges for Sustainable Development. Handbook and Abstracts from Conference at Can Tho University, Can Tho city, Vietnam, p.89, 2008.

[3] T.Q. Phu, and Y. Yi, "Anh huong cua viec nuoi ca da tron trong be den chat luong moi truong nuoc o huyen Hong Ngu, tinh Dong Thap," Scientific Journal of Can Tho University, vol. 199, pp. 8-17, 2003 (Vietnamese).

[4] H.D. Park, and D.R. Noguera, "Characteristization of two ammonia-oxidizing bacteria isolated from reactors operated with low dissolved oxygen concentrations," J. Appl. Microbiol., vol. 102, pp. 1401-1417, 2006.

[5] H.S. Joo, M. Hirai, and M. Sinoda, "Piggery wastewater treatment using Alcaligenes faecalis strain No. 4 with heterotrophic nitrification and aerobic denitrification," Water Res., vol. 40, pp. 3029-3036, 2006.

[6] J.J. Su, R.S. Yeh, and P.W. Tseng, “A strain of Pseudomonas sp. isolated from piggery wastewater treatment systems with heterotrophic nitrification capability in Taiwan," Curr. Microb., vol. 53, pp. 77-81, 2006.

[7] L.A. Robertson, E.W.J. Van Neil, R.A.M. Torremans, and J.G. Kuenen, "Simultaneous nitrification and denitrification in aerobic chemost at cultures of Thiosphaera pantotropha," Appl. Environ. Microb., vol. 54, pp. 2812-2818, 1988.

[8] H.S. Joo, M. Hiral, and M. Sinoda, "Characteristics of ammonium removal by heterotrophic nitrofication-aerobic denitrification by Alcaligenes faecalis No 4," J. Biosci. Bioeng., vol. 100, pp. 184-191, 2005.

[9] J.K. Kim, K.L. Park, R.S. Cho, S.W. Nam, T.J. Park, and R. Bajpal, "Aerobic nitrification-denitrification by heterotrophic Bacillus strains," Biores. Technol., vol. 96, pp. 1897-1906, 2005.

[10] B. Zhao, Y.L. He, J. Hughes, and X.F. Zhang, "Heterotrophic nitrogen removal by a newly isolated Acinetobacter calcoaceticus HNR," Biores. Technol., vol. 101, pp. 5194-5200, 2010 .

[11] H.J. Hoben, and P. Somasegaran, "Comparison of Pour, Spread and Drop Plate Methods for Enumeration of Rhizobium spp. in Inoculants made from Presterilized peat," Appl. Environ. Microbiol., vol. 44, pp. 1246-1247, 1982.

[12] B. Neumann, A. Pospiech, and H.U. Schairrer, "Rapid isolation of genomic DNA from Gram-negative," Trends Gent., vol. 8,pp. 332-333, 1992. 
[13] S. Turner, K.M. Pryer, V.P.M. Miao, and J.D. Palmer, "Investigating deep phylogenetic relationships among cyanobacteria and plastids by small subnit rRNA sequence analysis,” J. Eukaryotic Microbiol., vol. 46, pp. 327-338, 1999.

[14] K. Tamura, D. Peterson, N. Peterson, G. Stecher, M. Nei, and S. Kumar, "MEGA5: Molecular Evolutionary Genetics Analysis using Maximum Likehood, Evolutionary Distance and Maximum Parsimony Methods," Mol. Biol. Evol., vol. 28, pp. 2731-2739, 2011.

[15] M.K. Halushka, J.B. Fan, K. Bentley, L. Hsie, N. Shen, A. Weder, R. Cooper, R. Lipshutz, and A. Charavarti, "Patterns of single-nucleotide polymorphisms in candidate genes for blood-pressure homestasis," Nat. Genet., vol. 22(3), pp. 239-247, 1999.

[16] [16] G.A. Watterson, "On the number of segregation sites in general models without recombination," Theor. Pop. Biol., vol. 7, pp. 256-276, 1975.

[17] J. Rozas, and R. Rozas, "DnaSP version 4.1: an integrated program for molecular population genetics and molecular evolution analysis," Bioinformatics, vol. 15, pp. 174-175,
2005.

[18] T.G. Giang, V.N. Ut, and N.T. Phuong, "Bien dong cac yeu to moi truong trong ao nuoi ca tra (Pangasiadon hypophthalmus) tham canh o An Giang," Scientific journal of Can Tho University vol.1, pp. 1-9, 2008 (Vietnamese).

[19] [C.N. Diep, P.M. Cam, N.H. Vung, T.T. Lai, and N.T.X. My, "Isolation of Pseudomonas stutzeri in wastewater of catfish fish-ponds in the Mekong Delta and its application for wastewater treatment," Bioresoure Tech., vol. 100, pp. 3787-3791, 2009

[20] J.J. Su, Y.L. Liu, F.J. Shu, and J.F. Wu, "Treatment of piggery wastewater by contact aeration treatment in coordination of three-step piggery wastewater treatment (TPWT) process in Taiwan,” J. Environ. Sci. Health, vol. 32A, pp. 55-73, 1997.

[21] N.N. Nguyen, G.V. Thang, and P.V. Hai, "Survey and research for producing bacterial tablet to treat striped catfish pond environment at intensive scale," Aquaculture in Vietnam: Present Status and Challenges for Sustainable Development. Handbook and Abstracts from Conference at Can Tho University, Can Tho city, Vietnam, p.84, 2008. 